\title{
Pot-economic synthesis of diarylpyrazoles and pyrimidines involving Pd-catalyzed cross-coupling of 3-trifloxychromone and triarylbismuth
}

\author{
ABHIJEET KUMAR ${ }^{\mathrm{a}, \mathrm{b}, *}$ and MADDALI L N RAO ${ }^{\mathrm{b}}$ \\ ${ }^{a}$ Department of Chemistry, School of Physical and Material Sciences, Mahatma Gandhi Central University, \\ Motihari, Bihar 845 401, India \\ ${ }^{\mathrm{b}}$ Department of Chemistry, Indian Institute of Technology Kanpur, Kanpur, Uttar Pradesh 208 016, India \\ E-mail: abhijeetkumar@mgcub.ac.in
}

MS received 9 August 2018; revised 25 September 2018; accepted 2 October 2018; published online 26 November 2018

\begin{abstract}
The present study reveals the formation of 3,4-diarylpyrazole and 4,5-diarylpyrimidine in one-pot operation starting from 3-trifloxychromone and triarylbismuth. The complete process encompasses two steps in the one-pot operation. The first step leads to the formation of isoflavone via cross-coupling reaction of 3trifloxychromone and triarylbismuth as a threefold arylating reagent. These isoflavones were further converted into 3,4-diarylpyrazole and 4,5-diarylpyrimidine using hydrazine hydrate and guanidinium chloride in the successive step in the same pot. Interestingly the formation of 3,4-diarylpyrazole was achieved in the shortest reaction time i.e., $30 \mathrm{~min}$ that too at room temperature. Overall the developed methodology provides easy access to the medicinally important diarylpyrazole and pyrimidine moiety in one-pot operation and in short reaction time.
\end{abstract}

Keywords. Cross-coupling; triarylbismuth; isoflavones; diarylpyrazoles; diarylpyrimidines; pot-economy.

\section{Introduction}

Pyrazoles and pyrimidines are significant scaffolds present in several biologically active molecules as well as in drug molecules. ${ }^{1-10}$ These are known to exhibit a vast range of biological activities such as anti-tumour, ${ }^{3,4}$ anti-inflammatory, ${ }^{5}$ anti-depressant ${ }^{6}$ and so on. In particular, diaryl pyrazoles and pyrimidines are present as core moieties in a number of drugs and agrochemicals. Figure 1 shows example of few drugs with arylated pyrazole or pyrimidines as core scaffold which are being prescribed to treat various physiological disorders. For example, Celecoxib (Figure 1a), ${ }^{7}$ is an example of non-steroidal anti-inflammatory drug (NSAID) and is known to be COX-2 (cyclooxygenase-2) inhibitors. ${ }^{1}$ Rosuvastatin (Figure 1b) is a drug for cardiovascular disorders. ${ }^{8}$ Importantly, phenol substituted pyrazoles and pyrimidines have exhibited appealing biological properties. For example, 3,4-diarylpyrazole (Figure 1c) has been studied as heat shock protein inhibitors and with

\footnotetext{
*For correspondence
}

anti-cancer activities. ${ }^{4,9}$ Likewise pyrimidine-based compounds are known for various biological applications including as tubulin polymerization inhibitors (Figure 1d). ${ }^{10,11}$ Phenol-substituted pyrazoles can easily be converted to phenanthropyrazoles. ${ }^{12}$ Apart from that, pyrazole derivatives are also known to serve as insecticides, ${ }^{13}$ fungicides ${ }^{14}$ and as versatile ligands. ${ }^{15,16}$

There have been a few synthetic methods for the preparation of aryl substituted pyrazoles ${ }^{17-23}$ and pyrimidines. ${ }^{10,24,25}$ Among those, the phenol substituted pyrazoles and pyrimidines have been obtained using isoflavones as a precursor. The vast therapeutic value associated with these phenol substituted 3,4-diarylpyrazoles and 4,5-diaryl-2-aminopyrimidines prompted us to develop a pot-economic protocol for their synthesis involving in situ formation of isoflavones using triarylbismuths under Pd-catalyzed condition. ${ }^{26}$ Utilization of triarylbismuths with sub-stoichiometric loadings in cross-coupling reactions is practically useful in organic synthesis. ${ }^{27-33}$ It was envisaged that the isoflavones obtained from cross-coupling reaction using triarylbismuth could further be converted to 
3,4-diarylpyrazoles and pyrimidines in one-pot operation. For the cross-coupling step, it was decided to employ 3-trifloxychromone as electrophilic coupling partner as the reactivity of this substrate has not been investigated so far in couplings with triarylbismuth reagents. Overall, our aim was to develop efficient pot-economic methods for the synthesis of phenolsubstituted diarylpyrazoles and pyrimidines by clubbing cross-coupling step for the formation of isoflavone as well as their transformation to diarylpyrazoles and pyrimidines.

\section{Experimental}

\subsection{General}

For structural characterization, NMR spectra were recorded on JEOL-400 MHz (JNM ECS-400) spectrometer. WATERSQ-Tof Premier-HAB213, in addition to WATERS GCT Premier-CAB155 instrument, were used for HRMS measurements. The Bruker Vector 22 FTIR spectrometer was used in IR measurements. Standard drying methods were followed for the distillation of solvents prior to use. All the coupling reactions were performed using oven-dried Schlenk tubes under inert atmosphere conditions. The 3-trifloxychromones (1a-1e) required for coupling reactions were obtained following the literature procedures. ${ }^{34-36 a}$ The triarylbismuth compounds were prepared by adopting the known procedures. ${ }^{36 \mathrm{~b}-\mathrm{c}}$ All the products were isolated using column chromatography with silica gel (100-200 mesh) and GF-254 silica gel (Merck) for thin layer chromatography.

\subsection{Representative procedures for the preparation of 3-trifloxychromones (Scheme 1)}

(A) Representative procedure for the preparation of 2-aryl-3hydroxyflavones: ${ }^{34}$

Step 1: Preparation of (E)-1-(2-hydroxyphenyl)-3-(4methoxyphenyl)prop-2-en-1-one (1A): To an oven dried round bottom flask, 2'-hydroxyacetophenone $(5.0 \mathrm{~g}$, $36.72 \mathrm{mmol})$ and $p$-anisaldehyde $(4.5 \mathrm{~mL}, 36.72 \mathrm{mmol})$ were charged in ethanol. To this, sodium hydroxide $(6.3 \mathrm{~g}$, $157.8 \mathrm{mmol}$ ) was added at $0^{\circ} \mathrm{C}$ and the reaction mixture was allowed to stir at $\mathrm{rt}$ for $18 \mathrm{~h}$. After complete consumption of starting materials, acetic acid $(30 \% \mathrm{v} / \mathrm{v})$ was added to neutralize the reaction mixture. The precipitate obtained was filtered and washed with water. It was further purified through crystallization from ethanol to obtain compound $1 \mathrm{~A}$ as yellow solid in $80 \%$ yield $(7.4 \mathrm{~g})$.

Step 2: Preparation of 3-hydroxy-2-(4-methoxyphenyl)4H-chromen-4-one (2A): To an oven dried round bottom flask, compound 1A $(5.0 \mathrm{~g}, 19.6 \mathrm{mmol})$ was taken in ethanol. To this, sodium hydroxide $(1.5 \mathrm{~g}, 39.3 \mathrm{mmol})$ was added at ice-bath temperature. The mixture was stirred for $10 \mathrm{~min}$ and was added $\mathrm{H}_{2} \mathrm{O}_{2}(30 \% \mathrm{w} / \mathrm{v}, 5.0 \mathrm{~mL}$, $43.2 \mathrm{mmol}$ ). It was allowed to stir at $\mathrm{rt}$ for $18 \mathrm{~h}$. It was acidified with dil $\mathrm{HCl}$ and the yellow precipitate obtained was filtered and dried under vacuum. It was further purified by crystallization in ethanol to obtain $2 \mathrm{~A}$ in $73 \%$ yield $(3.8 \mathrm{~g})$.

(B) Representative procedures for the preparation of 3-hydroxychromones: ${ }^{35}$

Step 1: Preparation of (E)-3-(dimethylamino)-1-(2-hydroxyphenyl)prop-2-en-1-one (1B): To an oven dried round bottom flask, 2-hydroxyacetophenone $(10.0 \mathrm{~mL}$, $83.0 \mathrm{mmol})$ and $N, N$-dimethylformamide dimethyl acetal $(10.0 \mathrm{~mL}, 83.0 \mathrm{mmol})$ were charged. It was refluxed for $1 \mathrm{~h}$. The reaction mixture was cooled to rt. The red precipitate was filtered and washed with petroleum ether to get enamide, (E)-3-(dimethylamino)-1-(2-hydroxyphenyl) prop-2-en-1-one in $94 \%$ yield (19.8 g). It was used in the next step without further purification.

Step 2: Preparation of 4H-chromen-4-one (2B): To an oven dried round bottom flask, $(E)$-3-(dimethylamino)-1(2-hydroxyphenyl)prop-2-en-1-one (10.0 g, $53.0 \mathrm{mmol})$ was dissolved in dichloromethane $(50.0 \mathrm{~mL})$. To this, conc. $\mathrm{HCl}(50 \mathrm{~mL})$ was added and the mixture was refluxed for $1 \mathrm{~h}$. It was cooled to rt and poured into cold water. The organic layer was separated and the aqueous layer was extracted with dichloromethane $(2 \times 30 \mathrm{~mL})$. The combined organic extract was washed with water and brine and dried over anhydrous $\mathrm{MgSO}_{4}$. The solvent was evaporated and dried under vacuum to obtain $4 H$ chromen-4-one as red solid in 90\% yield $(6.8 \mathrm{~g})$.

Step 3: Preparation of 3-hydroxychromone (3B): To an oven dried round bottom flask $4 H$-chromen-4-one $(5.0 \mathrm{~g}$,

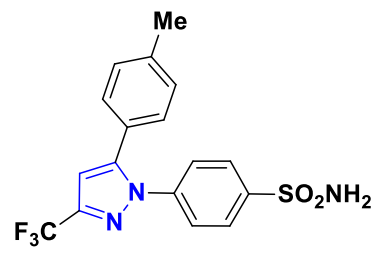

(a)

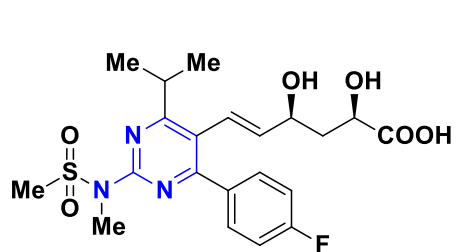

(b)

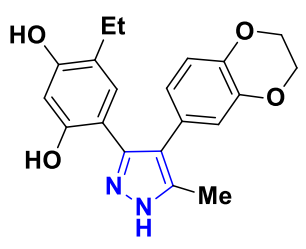

(c)

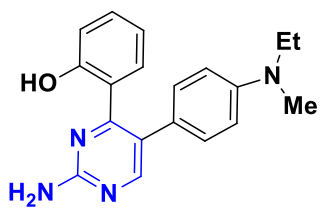

(d)

Figure 1. Pyrazole and pyrimidine-based biological scaffolds and drugs. 


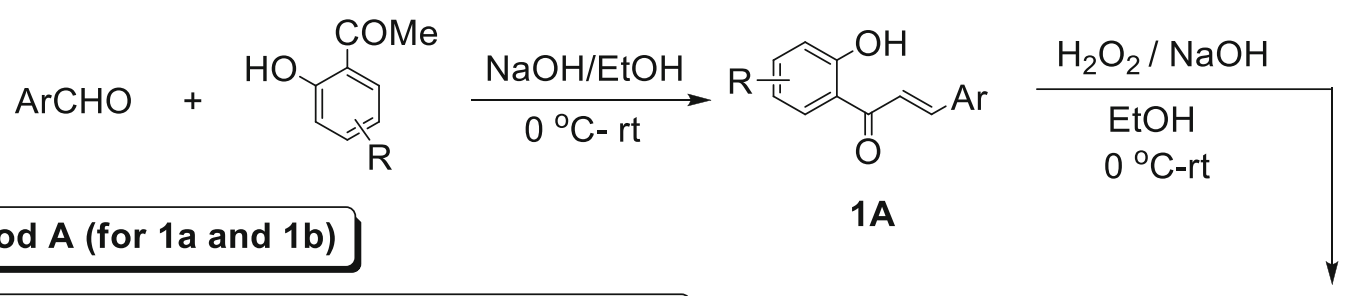

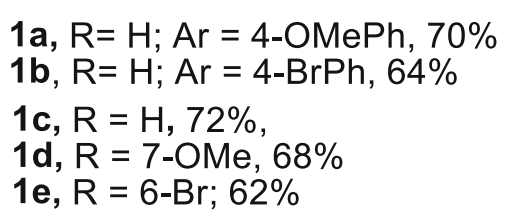

\section{Method B (for 1c-1e)}<smiles>[R]c1ccc(O)c(C(C)=O)c1</smiles>

1B

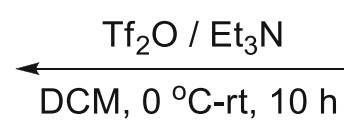<smiles>[R][CH][TeH]</smiles>

2A I 3B

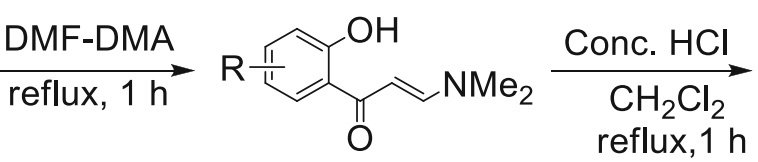

reflux, $1 \mathrm{~h}$

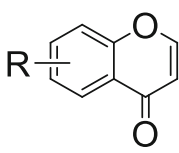

2B

Scheme 1. Synthesis of functionalized 3-trifloxychromones.

$34.2 \mathrm{mmol})$ was dissolved in dichloromethane $(50 \mathrm{~mL})$. Sodium hydroxide $(2.0 \mathrm{~g}, 51.3 \mathrm{mmol})$ was added to it. Reaction mixture was cooled to $0{ }^{\circ} \mathrm{C}$ and $\mathrm{H}_{2} \mathrm{O}_{2}(30 \%$ w/v, $13.5 \mathrm{~mL}, 119.7 \mathrm{mmol}$ ) was slowly added at the same temperature. After complete addition, the mixture was stirred at $0-15^{\circ} \mathrm{C}$. After complete disappearance of chromone as monitored by TLC, it was quenched with water and extracted with dichloromethane $(3 \times 20 \mathrm{~mL})$. The combined organic extract was washed with water and brine, dried over anhydrous $\mathrm{MgSO}_{4}$ and evaporated using rotatory evaporator. In the second step, conc. $\mathrm{HCl}$ $(50 \mathrm{~mL})$ was added to the crude reaction mixture and was stirred at $70^{\circ} \mathrm{C}$ for $1 \mathrm{~h}$. After that, it was cooled to $\mathrm{rt}$ and poured into water. The solid precipitate obtained was filtered and washed with water and dried under vacuum to obtain a white solid as 3 -hydroxychromone in $64 \%$ yield (3.54 g).

(C) Representative procedure for the preparation of triflate derivatives: ${ }^{36}$

To a two-neck round bottom flask 3-hydroxychromone $(5.0 \mathrm{~g}, 18.5 \mathrm{mmol})$ was charged in dry dichloromethane $(50 \mathrm{~mL})$. The mixture was cooled to $0^{\circ} \mathrm{C}$ and triethylamine $(3.0 \mathrm{~mL}, 22.2 \mathrm{mmol})$ was added with continuous stirring for $10 \mathrm{~min}$ followed by triflic anhydride $(4.6 \mathrm{~mL}$, $27.7 \mathrm{mmol}$ ) and the resultant mixture was allowed to stir at $\mathrm{rt}$ for $10 \mathrm{~h}$. After that, it was quenched with water and extracted with dichloromethane $(3 \times 20 \mathrm{~mL})$ and dried over anhydrous $\mathrm{MgSO}_{4}$ and concentrated. It was purified by silica gel column chromatography (5\% EtOAc/petroleum ether) to obtain 1c as white solid (3.9 g, 72\%).

\subsection{Representative procedure for cross-coupling reaction}

Representative cross-coupling procedure for Tables 1 and 2: A hot-oven dried Schlenk tube was charged with 1a $(0.164 \mathrm{~g}, \quad 0.412 \mathrm{mmol}), \quad$ tri(p-anisyl)Bi $(0.066 \mathrm{~g}$, $0.125 \mathrm{mmol}), \mathrm{Pd}\left(\mathrm{PPh}_{3}\right)_{4}(0.012 \mathrm{~g}, 0.011 \mathrm{mmol}), \mathrm{K}_{3} \mathrm{PO}_{4}$ $(0.053 \mathrm{~g}, 0.25 \mathrm{mmol})$, and DMF ( $3 \mathrm{~mL})$ under $\mathrm{N}_{2}$ atmosphere. The reaction mixture was stirred in an oil bath at $90^{\circ} \mathrm{C}$ for $4 \mathrm{~h}$. At the end of the reaction time, the contents were brought to rt, quenched with water $(10 \mathrm{~mL})$ and extracted with ethyl acetate. The organic extract was treated with brine, dried using $\mathrm{MgSO}_{4}$ and was concentrated under reduced pressure. The crude product was subjected to silica gel column chromatography using $10 \%$ EtOAc/petroleum ether as eluent to obtain product 2.1 as white solid $(0.109 \mathrm{~g}, 81 \%)$. For the yield calculation, $0.375 \mathrm{mmol}$ of the product was considered as $100 \%$ yield.

\subsection{Pot-economic synthesis of 2-(4-phenyl-1H-pyrazol-3-yl)phenol (3.1, Table 3)}

A hot-oven dried Schlenk tube was charged with 1c $(0.121 \mathrm{~g}, 0.412 \mathrm{mmol}), \mathrm{BiPh}_{3}(0.055 \mathrm{~g}, 0.125 \mathrm{mmol})$, $\mathrm{Pd}\left(\mathrm{PPh}_{3}\right)_{4}(0.012 \mathrm{~g}, 0.011 \mathrm{mmol}), \mathrm{K}_{3} \mathrm{PO}_{4}(0.053 \mathrm{~g}, 0.25 \mathrm{~mm}$ $\mathrm{ol}$ ), and DMF (3 $\mathrm{mL})$ under $\mathrm{N}_{2}$ atmosphere. The reaction mixture was stirred in an oil bath at $90^{\circ} \mathrm{C}$ for $4 \mathrm{~h}$. At the end of the reaction time, the contents were brought to $\mathrm{rt}$ and hydrazine hydrate $(0.03 \mathrm{~mL}, 0.625 \mathrm{mmol})$ was added to the reaction mixture. It was further stirred at $\mathrm{rt}$ for $30 \mathrm{~min}$. After it was quenched with water $(10 \mathrm{~mL})$ and extracted with ethyl acetate. 
Table 1. Screening for 3-trifloxychromone coupling. ${ }^{\mathrm{a}-\mathrm{e}}$

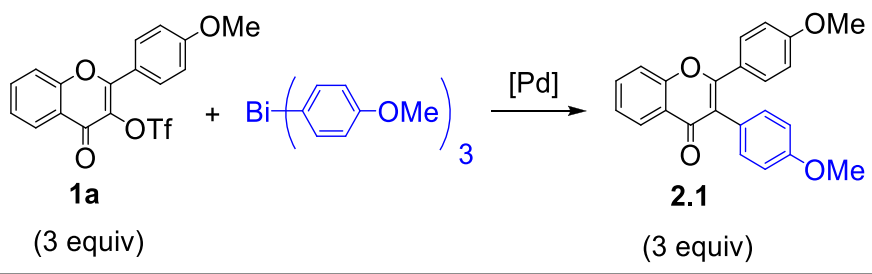

\begin{tabular}{|c|c|c|c|c|c|}
\hline Entry & Catalyst & Base (equiv.) & Temp. $\left({ }^{\circ} \mathrm{C}\right)$ & Solvent & Yield $2.1(\%)$ \\
\hline 1 & $\mathrm{PdCl}_{2}\left(\mathrm{PPh}_{3}\right)_{2}$ & $\mathrm{~K}_{3} \mathrm{PO}_{4}(6)$ & 90 & DME & 46 \\
\hline 2 & $\mathrm{Pd}\left(\mathrm{PPh}_{3}\right)_{4}$ & $\mathrm{~K}_{3} \mathrm{PO}_{4}$ & 90 & DMF & 58 \\
\hline 3 & $\mathrm{Pd}\left(\mathrm{PPh}_{3}\right)_{4}$ & $\mathrm{~K}_{3} \mathrm{PO}_{4}(2)$ & 90 & $\mathrm{DMF}$ & 81 \\
\hline 4 & $\mathrm{Pd}\left(\mathrm{PPh}_{3}\right)_{4}$ & $\mathrm{~K}_{3} \mathrm{PO}_{4}$ & 90 & $\mathrm{DMF}$ & 76 \\
\hline 5 & $\mathrm{Pd}\left(\mathrm{PPh}_{3}\right)_{4}$ & $\mathrm{~K}_{3} \mathrm{PO}_{4}(2)$ & 90 & DMA & 77 \\
\hline 6 & $\mathrm{Pd}\left(\mathrm{PPh}_{3}\right)_{4}$ & $\mathrm{~K}_{3} \mathrm{PO}_{4}(2)$ & 90 & NMP & 65 \\
\hline 7 & $\mathrm{Pd}\left(\mathrm{PPh}_{3}\right)_{4}$ & $\mathrm{Cs}_{2} \mathrm{CO}_{3}(2)$ & 90 & DMF & 54 \\
\hline 8 & $\mathrm{Pd}\left(\mathrm{PPh}_{3}\right)_{4}$ & $\mathrm{~K}_{2} \mathrm{CO}_{3}$ & 90 & $\mathrm{DMF}$ & 60 \\
\hline 9 & $\mathrm{Pd}\left(\mathrm{PPh}_{3}\right)_{4}$ & $\mathrm{~K}_{3} \mathrm{PO}_{4}(2)$ & 60 & DMF & 48 \\
\hline 10 & $\mathrm{Pd}\left(\mathrm{PPh}_{3}\right)_{4}$ & $\mathrm{~K}_{3} \mathrm{PO}_{4}(2)$ & 100 & DMF & 77 \\
\hline 11 & $\mathrm{Pd}\left(\mathrm{PPh}_{3}\right)_{4}$ & $\mathrm{~K}_{3} \mathrm{PO}_{4}(2)$ & 90 & DMF & $72^{\mathrm{c}}$ \\
\hline 12 & $\mathrm{Pd}\left(\mathrm{PPh}_{3}\right)_{4}$ & $\mathrm{~K}_{3} \mathrm{PO}_{4}(2)$ & 90 & $\mathrm{DMF}$ & $80^{\mathrm{d}}$ \\
\hline 13 & $\mathrm{Pd}\left(\mathrm{PPh}_{3}\right)_{4}$ & $\mathrm{~K}_{3} \mathrm{PO}_{4}(2)$ & 90 & $\mathrm{DMF}$ & $52^{\mathrm{e}}$ \\
\hline 14 & $\mathrm{Pd}\left(\mathrm{PPh}_{3}\right)_{4}$ & None & 90 & DMF & 30 \\
\hline 15 & None & $\mathrm{K}_{3} \mathrm{PO}_{4}(2)$ & 90 & DMF & None \\
\hline
\end{tabular}

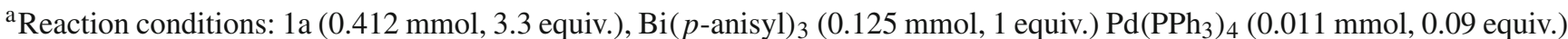
$\mathrm{K}_{3} \mathrm{PO}_{4}(0.25 \mathrm{mmol}, 2$ equiv. $)$, DMF $(3 \mathrm{~mL}), 4 \mathrm{~h}, 90^{\circ} \mathrm{C}$. ${ }^{\mathrm{b}}$ Isolated yields based on three aryl couplings from BiAr 3 reagents ${ }^{\mathrm{c}}$ With 3 h. ${ }^{\mathrm{d}}$ With $5 \mathrm{~h}$. ${ }^{\mathrm{e}}$ With 0.05 equiv. catalyst.

The organic extract was treated with brine, dried using $\mathrm{MgSO}_{4}$ and the solvent was concentrated under reduced pressure. The crude product was subjected to silica gel column chromatography using $15 \%$ EtOAc/petroleum ether as eluent to obtain 3.1 as white solid $(0.067 \mathrm{~g}, 76 \%)$.

\subsection{Pot-economic synthesis of \\ 2-(2-amino-5-phenylpyrimidin-4-yl)phenol (4.1, Table 5)}

The cross-coupling reaction with $1 \mathrm{c}$ was carried according to the procedure given in 2.3. After that, guanidinium chloride $(0.048 \mathrm{~g}, 0.5 \mathrm{mmol})$ and $\mathrm{NaOH}(0.050 \mathrm{~g}, 1.25 \mathrm{mmol})$ were added to the reaction mixture. It was further stirred at $90^{\circ} \mathrm{C}$ for $10 \mathrm{~h}$. The product mixture was quenched with water $(10 \mathrm{~mL})$ and neutralized with dil. $\mathrm{HCl}$. It was further extracted with ethyl acetate. The organic extract was treated with brine, dried using $\mathrm{MgSO}_{4}$ and concentrated under reduced pressure. The crude product was subjected to silica gel column chromatography using $10 \%$ EtOAc/dichloromethane as eluent to obtain product 4.1 as yellow solid $(0.078 \mathrm{~g}, 79 \%)$.

\section{Results and Discussion}

The required 3-trifloxychromones (1a-1e) for this investigation were accessed through literature procedures in good yields following method $\mathrm{A}$ and $\mathrm{B}$ as given in Scheme $1 .{ }^{34-36} \mathrm{Next}$, the cross-coupling reactivity of 3-trifloxychromones with triarylbismuth reagent was explored. It was investigated to establish an optimized protocol under Pd-catalyzed conditions (Table 1). It was done initially using 2-( $p$-methoxyphenyl)-3trifloxychromone (1a) and tri( $p$-anisyl $)$ bismuth using catalytic $\mathrm{PdCl}_{2}\left(\mathrm{PPh}_{3}\right)_{2}$ conditions and $\mathrm{K}_{3} \mathrm{PO}_{4}$ base in DME at $90{ }^{\circ} \mathrm{C}$ (entry 1 , Table 1$){ }^{26}$ This catalytic protocol furnished the desired isoflavone 2.1 in $46 \%$ yield (entry 1, Table 1). Another attempt using catalytic $\mathrm{Pd}\left(\mathrm{PPh}_{3}\right)_{4}$ afforded 2.1 in 58\% yield (entry 2, Table 1 ). However, it was dramatically improved to $81 \%$ yield when the reaction was performed with 2 equiv. of base (entry 3, Table 1). Further improvement was not seen with 3 equiv. of the base (entry 4, Table 1). At this stage, more investigations were carried out in different solvents using $N, N$-dimethylacetamide (DMA) and $N$ methyl-2-pyrrolidone (NMP).

In these cases, we did not witness any further improvement in the cross-coupling yield (entries 5 and 6, Table 1). The impact of $\mathrm{Cs}_{2} \mathrm{CO}_{3}$ and $\mathrm{K}_{2} \mathrm{CO}_{3}$ base condition proved to be ineffective (entries 7 and 8 , Table 1 ). The cross-couplings performed at 60 and $100{ }^{\circ} \mathrm{C}$ conditions found to be low yielding (entries 9 and 10, Table 1). Additional check with different time durations proved to 
Table 2. Cross-couplings of functionalized 3-trifloxychromones. ${ }^{\mathrm{a}-\mathrm{c}}$

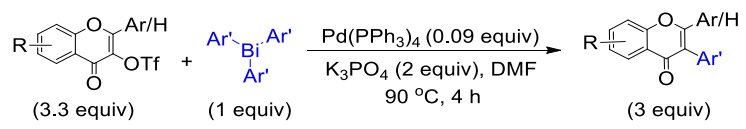

\begin{tabular}{|c|c|c|c|}
\hline Entry & 3-Trifloxychromone & Product & Yield (\%) \\
\hline 1 & & & 81 \\
\hline 2 & & & 65 \\
\hline 3 & $1 \mathrm{~b}$ & 2.3 & 68 \\
\hline 4 & $1 \mathrm{~b}$ & 2. & 67 \\
\hline 5 & 100 & 2.5 & 78 \\
\hline 6 & & 2.6 & 75 \\
\hline 7 & c & 2.7 & 79 \\
\hline 8 & & 2.8 & 77 \\
\hline 9 & $1 \mathrm{c}$ & 2.9 & 82 \\
\hline 10 & $1 \mathrm{c}$ & 2.10 & 79 \\
\hline 11 & $1 \mathrm{c}$ & 2.11 & 65 \\
\hline 12 & 1c & 2.12 & 71 \\
\hline 13 & 1d & 2.13 & 75 \\
\hline 14 & 1d & 2.14 & 82 \\
\hline 15 & & & 82 \\
\hline 16 & & 2.16 & 73 \\
\hline 17 & & 2.17 & 62 \\
\hline 18 & $1 \mathrm{e}$ & 2.18 & 64 \\
\hline 19 & 1e & 2.19 & 64 \\
\hline
\end{tabular}

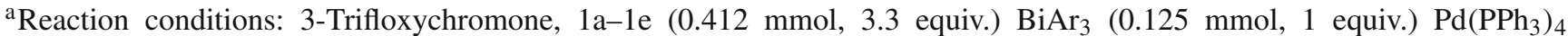
(0.011 mmol, 0.09 equiv.) $\mathrm{K}_{3} \mathrm{PO}_{4}\left(0.25 \mathrm{mmol}, 2\right.$ equiv.) $\mathrm{DMF}(3 \mathrm{~mL}), 90^{\circ} \mathrm{C}, 4 \mathrm{~h} .{ }^{\mathrm{b}}$ Isolated yields based on threefold coupling from triarylbismuth reagents and $0.375 \mathrm{mmol}$ corresponds to a $100 \%$ yield. ${ }^{\mathrm{c}} \mathrm{Homo}-\mathrm{coupled}$ biaryls formed $10-15 \%$ amounts. 
Table 3. Pot-economic synthesis of 3,4-diaryl-1 $H$-pyrazoles. ${ }^{\text {a-c }}$

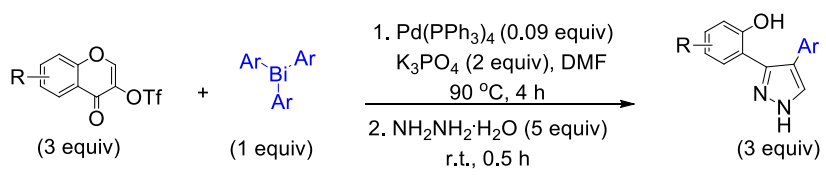

\begin{tabular}{|c|c|c|c|}
\hline Entry & 3-Trifloxychromone & 3,4-Diarylpyrazole & Yield (\%) \\
\hline 1 & $1 \mathrm{c}$ & & 76 \\
\hline 2 & & & 72 \\
\hline 3 & $1 \mathrm{c}$ & & 80 \\
\hline 4 & 1c & 3.4 & 67 \\
\hline 5 & 1c & 3.5 & 71 \\
\hline 6 & 1c & 3.6 & 74 \\
\hline 7 & 1c & 3.7 & 60 \\
\hline 8 & $1 \mathbf{c}$ & 3.8 & 78 \\
\hline 9 & $1 \mathrm{c}$ & 3.9 & 78 \\
\hline 10 & 1c & 3.10 & 74 \\
\hline 11 & 1c & 3.11 & 66 \\
\hline 12 & 10 & 3.12 & 75 \\
\hline 13 & Id & $\begin{array}{c}{ }^{H O}{ }^{n} \\
\text { 3.13 }\end{array}$ & 55 \\
\hline 14 & 1e & 3.14 & 62 \\
\hline
\end{tabular}

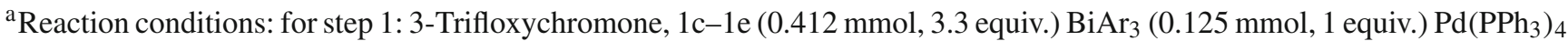
(0.011 mmol, 0.09 equiv.) $\mathrm{K}_{3} \mathrm{PO}_{4}\left(0.25 \mathrm{mmol}, 2\right.$ equiv.) $\mathrm{DMF}(3 \mathrm{~mL}), 90{ }^{\circ} \mathrm{C}, 4 \mathrm{~h}$ for Step 2: hydrazine hydrate $(0.625 \mathrm{mmol}$, 5 equiv.) rt, 0.5 h. ${ }^{b}$ Isolated yields based on threefold coupling from triarylbismuth reagents and 0.375 mmol of $3.4-$ diarylpyrazole corresponds to a $100 \%$ yield. ${ }^{\mathrm{c}}$ Homo-coupled biaryls formed $10-15 \%$ amounts. 


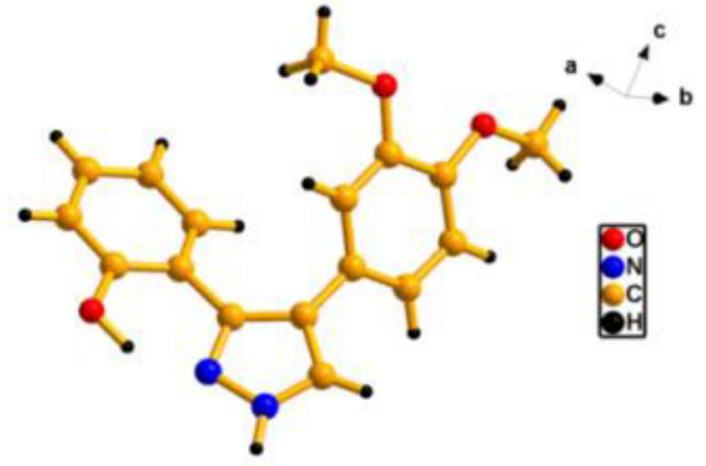

Figure 2. X-ray structural analysis for 3.10 (CCDC No. 1412753). ${ }^{39}$

be less effective (entries 11 and 12, Table 1). To optimize the catalyst loading, a coupling reaction was performed with 0.05 equiv. of catalyst and this gave $52 \%$ yield (entry 13, Table 1). The absence of either base or catalyst proved to be ineffective as they were crucial for an effective coupling process (entries 14 and 15, Table 1).

With this study, it was realized that the protocol involving $\mathrm{Pd}\left(\mathrm{PPh}_{3}\right)_{4}$ ( 0.09 equiv.) and $\mathrm{K}_{3} \mathrm{PO}_{4}$ (2 equiv.) in $\mathrm{DMF}$ at $90{ }^{\circ} \mathrm{C}$ for $4 \mathrm{~h}$ as promising for the effective cross-coupling of 3-trifloxychromone with triarylbismuth reagent (entry 3, Table 1). With this optimized protocol, the cross-coupling reactivity of various functionalized 3-trifloxychromones was further investigated (Table 2). The coupling reaction of 1a was first evaluated against different triarylbismuth reagents. This study delivered a facile cross-coupling performance with the formation of differently functionalized isoflavones in good to high yields (entries 1-19, Table 2). Further, this also revealed the possibility for chemo-selective couplings when the reactive bromo group in $1 \mathrm{~b}$ and 1e got survived during the coupling course under the optimized conditions (entries 3-5 and 17-19, Table 2). Other studies with electronically variant triphenylbismuth reagents also demonstrated viable reactivity under our optimized conditions (entries 6-12, Table 2). Even the vinyl group was intact when coupling was performed with vinyl substituted triphenylbismuth reagent (entry 6 , Table 2). This amply reflected the overall efficacy of the established palladium protocol conditions to deliver a library of isoflavones in high yields. Encouraged by this, it was further decided to explore a pot-economic protocol by combining the cross-coupled synthesis of isoflavones and their in situ conversion to either 3,4diarylpyrazoles or 4,5-diarylpyrimidines. For example, a brief literature search revealed that such transformation of isoflavone to pyrazole was performed with the direct reaction of isoflavones with hydrazine or after the
Table 4. Screening for pyrimidine formation. ${ }^{\mathrm{a}-\mathrm{b}}$

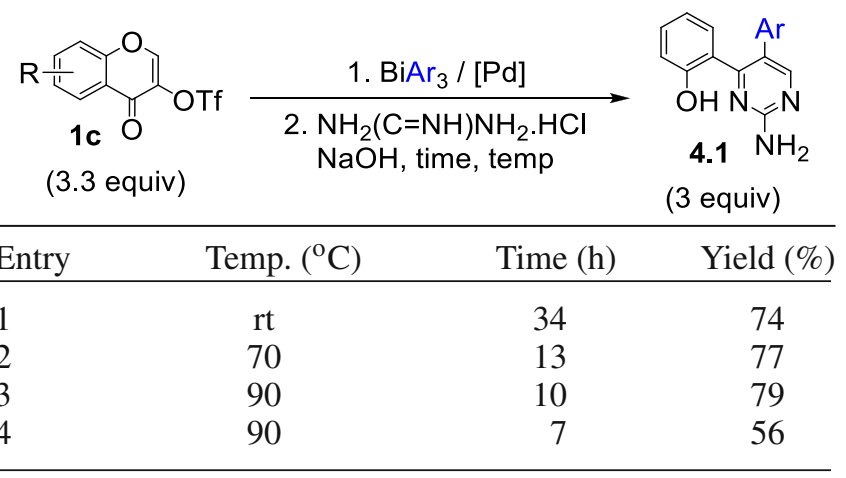

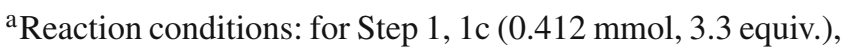
$\mathrm{BiAr}_{3}$ (0.125 mmol, 1 equiv.), $\mathrm{Pd}\left(\mathrm{PPh}_{3}\right)_{4}$ (0.011 mmol, 0.09 equiv.), $\mathrm{K}_{3} \mathrm{PO}_{4}$ ( $0.25 \mathrm{mmol}, 2$ equiv.), DMF (3 mL), $90^{\circ} \mathrm{C}, 4 \mathrm{~h}$ for Step 2, guanidinium chloride $(0.5 \mathrm{mmol}$, 4 equiv. $), \mathrm{NaOH}$ (1.25 mmol, 10 equiv. $)$, temp., time. ${ }^{\mathrm{b}}$ Isolated yields.

cross-coupling process. ${ }^{22,23}$ This search also revealed that not many pot-economic protocols were readily available with a possibility to combine two or more reactions in a one-pot operation. Further, the known protocol in this regard requires longer reaction time for access 3,4-diarylpyrazoles in a one-pot operation and this encouraged us to further explore any further improvement. Hence additional efforts were made with a view to developing a pot-economic combined protocol for the synthesis of 3,4-diarylpyrazoles using our rapid protocol conditions. To start with, it was done with the addition of hydrazine hydrate to the reaction mixture obtained after the cross-coupling step. Quantitative formation of 3,4diarylpyrazole was observed at $\mathrm{rt}$ in just $0.5 \mathrm{~h}$ conditions.

As reported, this transformation with an organoboron reagent such as arylboronic acid under the Suzuki coupling conditions requires longer reaction time. ${ }^{22}$ Hence it was of interest to further expand the scope for the development of a viable method for rapid access of pyrazoles in a one-pot operation. This resulted in the preparation of a library of 3,4-diarylpyrazoles and these results are as given in Table 3 . This pot-economic protocol involving cross-couplings with triarylbismuths followed by reaction with hydrazine afforded a variety of 3,4-diarylpyrazoles in a facile manner.

In general, the fast formation of 3,4-diarylpyrazoles was achieved when differently functionalized isoflavones were smoothly transformed under our pot-economic protocol conditions. We also obtained single crystal Xray analysis of 3.10 (Figure 2) and this unequivocally established the formation of 3,4-diarylpyrazole.

It further encouraged us to establish a pot-economic protocol for the synthesis of various 4,5-diarylpyrimidines. It was done through the initial generation of 
Table 5. Pot-economic synthesis of 4,5-diaryl 2-amino-pyrimidines. ${ }^{\text {a-c }}$

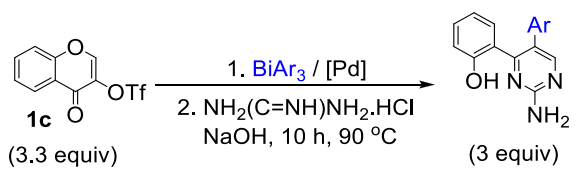

\begin{tabular}{|c|c|c|c|}
\hline Entry & 3-Trifloxychromone & 4,5-diaryl 2-aminopyrimdines & Yield (\%) \\
\hline 1 & $1 \mathrm{c}$ & 4.1 & 79 \\
\hline 2 & $1 \mathrm{c}$ & $4.2^{\mathrm{NH}_{2}}$ & 74 \\
\hline 3 & 1c & $\begin{array}{r}\mathrm{NH}_{2} \\
\mathbf{4 . 3} \\
\end{array}$ & 68 \\
\hline 4 & $1 \mathrm{c}$ & $\mathbf{4 . 4}$ & 79 \\
\hline 5 & $1 \mathrm{c}$ & $4.5^{\mathrm{NH}_{2}}$ & 61 \\
\hline 6 & $1 \mathrm{c}$ & 4.6 & 68 \\
\hline 7 & 1c & 4.7 & 72 \\
\hline
\end{tabular}

${ }^{a}$ Reaction conditions: for step 1, 1c (0.412 mmol, 3.3 equiv.), $\mathrm{BiAr}_{3}(0.125 \mathrm{mmol}, 1$ equiv. $\left.), \mathrm{Pd}_{(\mathrm{PPh}}\right)_{4}(0.011 \mathrm{mmol}$, 0.09 equiv.), $\mathrm{K}_{3} \mathrm{PO}_{4}(0.25 \mathrm{mmol}, 2$ equiv. $)$, DMF $(3 \mathrm{~mL}), 90^{\circ} \mathrm{C}, 4 \mathrm{~h}$ For step 2 , guanidinium chloride (0.5 mmol, 4 equiv.), $\mathrm{NaOH}$ (1.25 mmol, 10 equiv.), $90^{\circ} \mathrm{C}, 10 \mathrm{~h}$. ${ }^{\mathrm{b}}$ Isolated yields based on threefold coupling from triarylbismuth reagents and $0.375 \mathrm{mmol}$ of pyrimidine corresponds to a $100 \%$ yield. ${ }^{\mathrm{c}}$ Homo-coupled biaryls formed $10-15 \%$ amounts.

isoflavone followed by its reaction with guanidinium chloride in a one-pot operation. A trial reaction was initially carried out with guanidinium chloride after the cross-coupling step at room temperature. It delivered $74 \%$ of 4,5-diaryl-pyrimidine (4.1) in $34 \mathrm{~h}$ reaction time (entry 1 , Table 4$)$. In order to reduce the reaction time, the reaction condition was investigated by optimizing the reaction temperature (entries 2 and 3, Table 4). At $90^{\circ} \mathrm{C}$, quantitative conversion of isoflavone to 4,5diarylpyridimine was achieved in $10 \mathrm{~h}$ (entry 3 , Table 4). On decreasing the reaction time at the same temperature, the yield of 4,5-diarylpyrimidine decreased to $56 \%$ (entry 4, Table 4).

Reaction attempted without the addition of base in the second step did not provide desired 4,5-diarylpyrimidine (4.1). Hence further study for the conversion

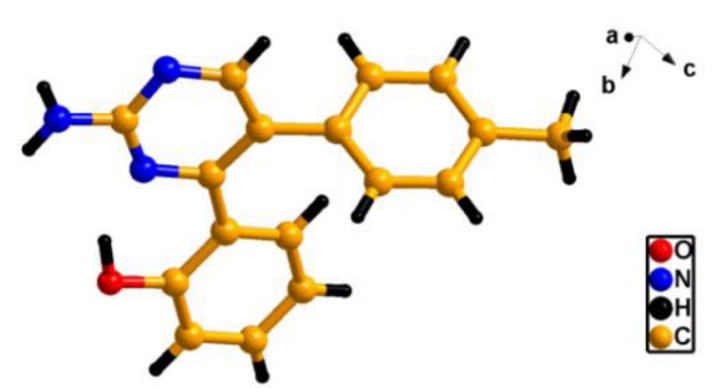

Figure 3. X-ray structural analysis of 4.4 (CCDC No. 1412754). ${ }^{39}$

of isoflavone to 4,5-diarylpyrimidine was continued with $90^{\circ} \mathrm{C}$ and $10 \mathrm{~h}$ condition in presence of an additional base in a second step. This optimized reaction 


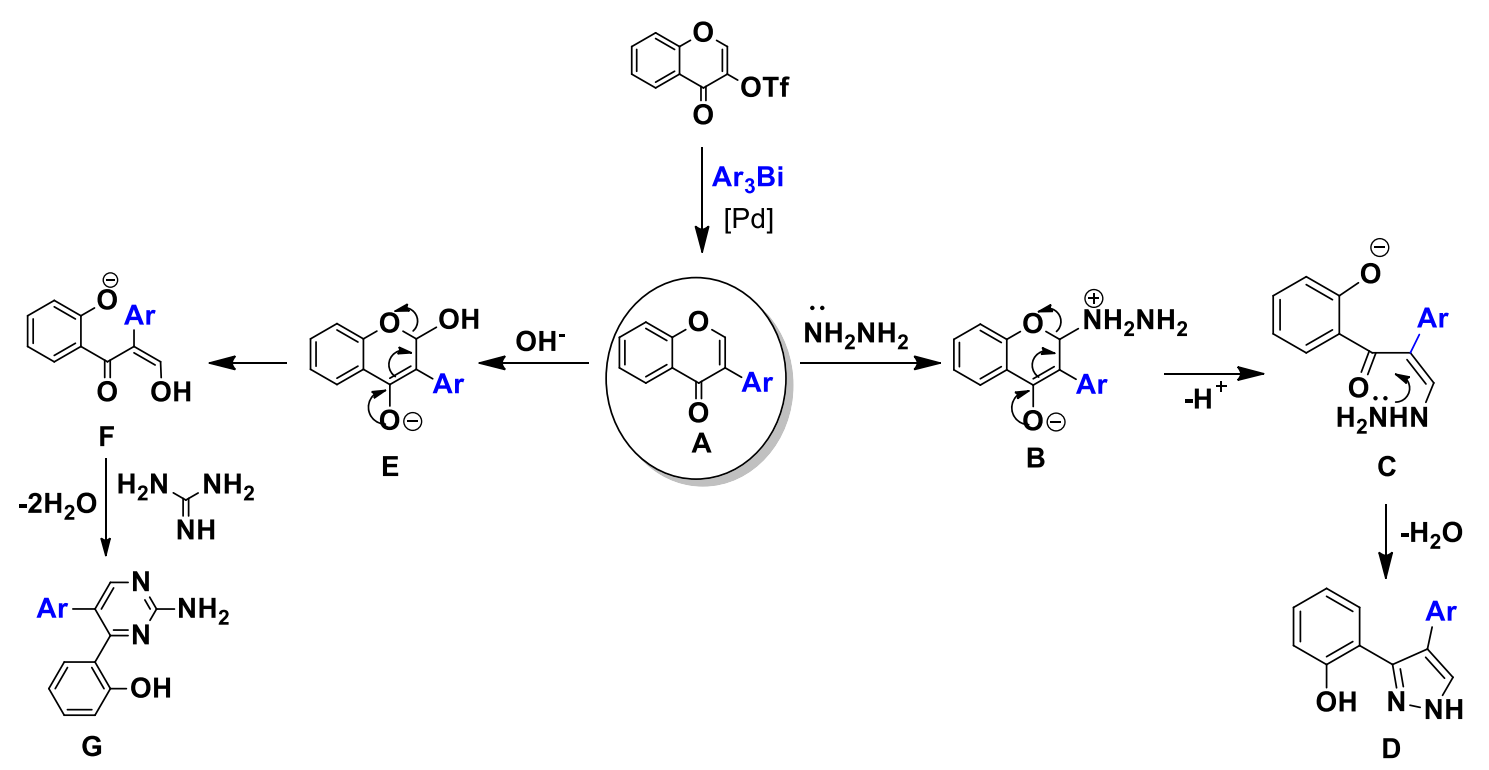

Figure 4. Proposed mechanism for the formation of diarylpyrazole and pyrimidine.

condition was applied in the synthesis of various functionalized 4,5-diarylpyrimidines (Table 5). The cross-coupling of $1 \mathrm{c}$ was carried out with different triarylbismuth reagents followed by the reaction of guanidinium chloride. This pot-economic protocol thus gave 4,5-diarylpyrimidines (4.1-4.7) in good to high yields. It is notable that this pot-economic protocol for the preparation of 4,5-diarylpyrimidines is synthetically more viable as it involves triarylbismuth reagents in substoichiometric loading with faster reactivity and overall high yields. Our efforts thus unequivocally established the compatibility of triarylbismuth cross-coupling conditions in further developing pot-economic combined protocols for rapid access of 3,4-diarylpyrazoles and 4,5-diarylpyrimidines in high yields.

Further, the crystal structure obtained for 2-(2-amino5-arylpyrimidin-4-yl) phenol (4.4) is given in Figure 3. Overall, an easy accessibility of isoflavones through cross-couplings under catalytic palladium conditions and their subsequent cyclocondensation to give 3,4diarylpyrazoles under pot-economic protocol conditions is expected to have a definitive advantage in organic synthesis. ${ }^{24}$ And this advantage also applies to the transformation of isoflavones with guanidine to rapid access to 4,5-diarylpyrimidines under pot-economic protocol conditions.

\subsection{Mechanism}

As shown in Figure 4, the formation of 3,4-diarylpyrazoles and 4,5-diarylpyrimidines involves the initial formation of isoflavones (A) through Pd-catalyzed cross-coupling reaction. ${ }^{26}$

In the second step, it was expected to undergo cyclocondensation with hydrazine involving nucleophilic attack of hydrazine (B), ring opening (C) followed by cyclocondensation to give 3,4-diarylpyrazole (D). ${ }^{12}$ Whereas the formation of 4,5-diarylpyrimidines is expected to begin with the base-mediated ring opening of isoflavone ${ }^{37,38}$ leading to $\mathrm{F}$ which undergoes condensation with guanidine to give 4,5- diarylpyrimidine $(\mathrm{G})$.

\section{Conclusions}

We have disclosed an efficient method for the synthesis of 3,4-diarylpyrazoles and 4,5-diarylpyrimidines starting with triarylbismuth as threefold arylating reagent and 3-trifloxychromones. These pot-economic protocols provide the rapid access to medicinally important 3,4-diarylpyrazoles and 4,5-diarylpyrimidines in high yields. It is important to highlight that 3,4diarylpyrazoles can be obtained at room temperature and within $30 \mathrm{~min}$ reaction time, the shortest time reported so far.

\section{Supplementary Information (SI)}

Characterization data and spectra $\left({ }^{1} \mathrm{H},{ }^{13} \mathrm{C}\right.$ NMR, Mass $)$ of the compounds included in Tables 2, 3, 5 are given in the supplementary information which is available at www.ias.ac. in/chemsci. 


\section{Acknowledgements}

We acknowledge the financial support (No. 02(0091)/12/ EMR-II) received from the Council of Scientific and Industrial Research (CSIR), New Delhi for this work. A.K. sincerely acknowledges the support of Scientific and Industrial Research (CSIR), New Delhi for fellowships and also thanks IIT Kanpur for providing financial assistance and infrastructure. He sincerely acknowledges the support for Mahatma Gandhi Central University for providing all other support.

\section{References}

1. Kucukguzel Guniz S and Senkardes S 2015 Recent advances in bioactive pyrazoles Eur. J. Med. Chem. 97 786

2. Lagoja I M 2005 Pyrimidine as constituent of natural biologically active compounds Chem. Biodivers. 21

3. Daidone G, Maggio B, Plescia S, Raffa D, Musiu C, Milia C, Perra G and Marongiu M E 1998 Antimicrobial and antineoplastic activities of new 4-diazopyrazole derivatives Eur. J. Med. Chem. 33375

4. Zaninetti R, Cortese S V, Aprile S, Massarotti A, Canonico P L, Sorba G, Grosa G, Genazzani A A and Pirali T 2013 A concise synthesis of pyrazole analogues of combretastatin A1 as potent anti-tubulin agents ChemMedChem 8633

5. Badawey E-S A M and El-Ashmawey I M 1998 Nonsteroidal antiinflammatory agents-part 1: antiinflammatory, analgesic and antipyretic activity of some new 1(pyrimidin-2-yl)-3-pyrazolin-5-ones and 2-(pyrimidin2-yl)-1,2,4,5,6,7-hexahydro-3 $H$-indazol-3-ones Eur. $J$. Med. Chem. 33349

6. Abdel-Aziz M, Abuo-Rahma GEl-din A and Hassan A A 2009 Synthesis of novel pyrazole derivatives and evaluation of their antidepressant and anticonvulsant activities Eur. J. Med. Chem. 443480

7. Datar P A and Jadhav S R 2014 Development of pyrazole compounds as antidiabetic agent: a review Lett. Drug Design Discov. 11686

8. Tartaggia S, Ferrari C, Pontini M and Luchhi O D 2015 A practical synthesis of rosuvastatin and other statin intermediates Eur. J. Org. Chem. 20154102

9. Cheung K-M J, Matthews T P, James K, Rowlands M G, Katherine J, Boxall K J, Sharp S Y, Maloney A, Roe S M, Prodromou C, Pearl L H, Aherne G W, McDonald E and Workman P 2005 The identification, synthesis, protein crystal structure and in vitro biochemical evaluation of a new 3,4-diarylpyrazole class of Hsp90 inhibitors Bioorg. Med. Chem. Lett. 153338

10. Xie F, Zhao H, Li D, Chen H, Quan H, Shi X, Lou L and $\mathrm{Hu}$ Y 2011 Synthesis and biological evaluation of 2,4,5-substituted pyrimidines as a new class of tubulin polymerization inhibitors J. Med. Chem. $\mathbf{5 4} 3200$

11. Xie F, Zhao H, Zhao L, Lou L and Hu Y 2009 Synthesis and biological evaluation of novel 2,4,5-substituted pyrimidine derivatives for anticancer activity Bioorg. Med. Chem. Lett. 19275

12. Wang Q, Zhang Z, Du Z, Hua H and Chen S 2013 One-pot synthesis of $2 \mathrm{H}$-phenanthro[9,10-c]pyrazoles from isoflavones by two dehydration processes Green Chem. 151048

13. Jiang D, Zheng X, Shao G, Ling Z and Xu H 2014 Discovery of a novel series of phenyl pyrazole inner salts based on fipronil as potential dual-target insecticides $J$. Agric. Food Chem. 623577

14. Wu Z, Hu D, Kuang J, Cai H, Wu S and Xue W 2012 Synthesis and antifungal activity of $N$-(substituted pyridinyl)-1-methyl(phenyl)-3-(trifluoromethyl)- $1 H$ pyrazole-4 carboxamide derivatives Molecules $\mathbf{1 7}$ 14205

15. Mukherjee R 2000 Coordination chemistry with pyrazole-based chelating ligands: molecular structural aspects Coord. Chem. Rev. 203151

16. Ward M D, McCleverty J A and Jeffery J C 2001 Coordination and supramolecular chemistry of multinucleating ligands containing two or more pyrazolyl-pyridine 'arms' Coord. Chem. Rev. 222251

17. Vanjari R, Guntreddi $\mathrm{T}$, Kumar $\mathrm{S}$ and Singh $\mathrm{K}$ N 2015 Sulphur promoted $\mathrm{C}\left(\mathrm{sp}^{3}\right)-\mathrm{C}\left(\mathrm{sp}^{2}\right)$ cross dehydrogenative cyclisation of acetophenone hydrazones with aldehydes: efficient synthesis of 3,4,5-trisubstituted $1 \mathrm{H}$ pyrazoles Chem. Commun. $\mathbf{5 1} 366$

18. Perez-Aguilar M C and Valdes C 2013 Regioselective one-step synthesis of pyrazoles from alkynes and N-tosylhydrazones: [3+2] dipolar cycloaddition/[1,5] sigmatropic rearrangement cascade Angew. Chem. Int. Ed. $\mathbf{5 2} 7219$

19. Tasch B O A, Bensch L, Antovic D and Müller T J J 2013 Masuda borylation-Suzuki coupling (MBSC) sequence of vinylhalides and its application in a one-pot synthesis of 3,4-biarylpyrazoles Org. Biomol. Chem. 116113

20. Hao L, Hong J-J, Zhu J and Zhan Z-P 2013 One-pot synthesis of pyrazoles through a four-step cascade sequence Chem. Eur. J. 195715

21. Heller S T and Natarajan S R 2006 1,3-Diketones from acid chlorides and ketones: a rapid and general one-pot synthesis of pyrazoles Org. Lett. 82675

22. Xie F, Cheng G and Hu Y 2006 Three-component, one-pot reaction for the combinatorial synthesis of 1,3,4substituted pyrazoles J. Comb. Chem. 8286

23. Zhang Z-T, Tan D-J and Xue D 2007 A concise onepot synthesis of 3,4-diaryl-1 $H$-pyrazoles from natural isoflavones and hydrazine hydrate Helv. Chim. Acta 90 2096

24. Zhang Z-T, Xu F-F, Gao M-X and Qiu L 2009 Onepot synthesis of 4,5-biphenyl-2-pyrimidinylguanidine derivatives J. Comb. Chem. 11880

25. Frasinyuk M S, Bondarenko S P and Khilya V P 2006 Reaction of analogs of natural isoflavonoids with amidines Chem. Nat. Comp. 42673

26. Rao M L N, Venkatesh V and Jadhav D N 2009 Pdcatalyzed efficient cross-couplings of 3-iodochromones with triaryl-bismuths as substoichiometric multicoupling organometallic nucleophiles Synlett 162597

27. Dawood K M 2007 Microwave-assisted SuzukiMiyaura and Heck-Mizoroki cross-coupling reactions of aryl chlorides and bromides in water using stable benzothiazole-based palladium(II) precatalysts Tetrahedron 639642

28. Felpin F-X 2005 Practical and efficient Suzuki-Miyaura cross-coupling of 2-iodocycloenones with arylboronic 
acids catalyzed by recyclable $\mathrm{Pd}(0) / \mathrm{C}$ J. Org. Chem. 70 8575

29. Akrawi O A, Patonay $\mathrm{T}$, Konya $\mathrm{K}$ and Langer $\mathrm{P}$ 2013 Chemoselective Suzuki-Miyaura cross-coupling reactions of 6-bromo-3- (trifluoromethylsulfonyloxy) flavones Synlett 240860

30. Zhang Z, Qiao J, Wang D, Han L and Ding R 2014 Synthesis of isoflavones by room-temperature nickelcatalyzed cross-couplings of 3-iodo(bromo)chromones with arylzincs Mol. Divers. 18245

31. Klier L, Bresser T, Nigst T A, Karaghiosoff $\mathrm{K}$ and Knochel P 2012 Lewis acid-triggered selective zincation of chromones, quinolones, and thiochromones: application to the preparation of natural flavones and isoflavones J. Am. Chem. Soc. 13413584

32. Vasselin D A, Westwell A D, Matthews C S, Bradshaw T D and Stevens M F G 2006 Structural studies on bioactive compounds. 40.(1) synthesis and biological properties of fluoro-, methoxyl-, and amino-substituted 3-phenyl-4H-1-benzopyran-4-ones and a comparison of their antitumor activities with the activities of related 2phenylbenzothiazoles J. Med. Chem. 493973

33. Tsoi Y-T, Zhou Z, Chan A S C and Yu W-Y 2010 Palladium-catalyzed oxidative cross-coupling reaction of arylboronic acids with diazoesters for stereoselective synthesis of $(E)-\alpha, \beta$-diarylacrylates Org. Lett. 124506

34. Kurzwernhart A, Kandioller W, Bächler S, Bartel C, Martic S, Buczkowska M, Mühlgassner G, Jakupec M A, Kraatz H-B, Bednarski P J, Arion V B, Marko D, Keppler B K and Hartinger C G 2012 Structure-activity relationships of targeted $\mathrm{Ru}^{\mathrm{II}}\left(\eta^{6}-p\right.$-cymene) anticancer complexes with flavonol-derived ligands J. Med. Chem. 5510512

35. Spadafora M, Postupalenko V Y, Shvadchak V V, Klymchenko A S, Mely Y, Burger A and Benhida R 2009 Efficient synthesis of ratiometric fluorescent nucleosides featuring 3-hydroxychromone nucleobases Tetrahedron 657809

36. (a) Rao M L N and Kumar A 2015 Pd-catalyzed cross-coupling study of bi-functional 3-bromo-4trifloxycoumarins with triarylbismuth reagents Tetrahedron 71 5137; (b) Finet J-P and Fedorov A Y 2006 J. Organomet. Chem. 691 2386; (c) De Ketelaere R F, Delbeke F T and Van Der Kelen G P 1971 J. Organomet. Chem. 30365

37. Wang J, Zhang Z, Wang W and Liu F 2013 Onestep synthesis of 5,6-diaryl pyridine-2(1H)-thiones from isoflavones Org. Biomol. Chem. 112034

38. Varga M, Batori S, Kövari-Radkai M, Prohaszka-Nemet I, Vitanyi-Morvai M, Böcskey Z, Bokotey S, Simon K and Hermecz I 2001 Stability and chemical reactivity of 7-isopropoxyisoflavone (ipriflavone) Eur. J. Org. Chem. 3911

39. CCDC-1412753 and CCDC-1412754 contains all crystallographic details for compounds 3.10 and 4.4 respectively. It is available free of charge at www.ccdc.cam. ac.uk/conts/-retrieving.html or can be ordered from the following address: Cambridge Crystallographic Data Centre, 12 Union Road, GB-Cambridge CB21EZ Fax: (+44)1223-336-033 or deposit@ ccdc.cam.ac.uk 